\title{
Historical perspectives of The American Association for Thoracic Surgery: Edward S. Welles (1891-1967)
}

\author{
Marc R. Moon, MD, ${ }^{a}$ and Stephen D. Cassivi, MD, MSc ${ }^{\mathrm{b}}$
}

Edward Sawtelle Welles, 34th president of The American Association for Thoracic Surgery (AATS), was born in Marshalltown, Iowa, on April 15, 1891, to Florence and Edward W. Welles. After graduation from Iowa State with a degree in electrical engineering, he received a scholarship to attend Harvard Medical School. He was to graduate in 1917, but shortly after the American declaration of war against the Imperial Government early that year, Dr Harvey Cushing, Chief of Surgery at Peter Bent Brigham in Boston, organized the Harvard Volunteer Surgical Unit to support the British Expeditionary Forces in Belgium. ${ }^{1,2}$ While still a medical student, Captain Welles ipso facto became the chief chest surgeon of a field hospital in Flanders on the Western Front (Figure 1). ${ }^{1}$ Welles operated at a grueling pace in austere conditions, often interrupted to take cover from incoming bombs. He somberly remembered weeping when the Scottish Regiments marched by on their way to the front to "die and suffer" in the mud-soaked trenches. ${ }^{3}$ The pivotal battle of Ypres that first summer ended when the British Forces recaptured Passchendaele, later described as a "smudge of ruins which had been the village." 2 With members of the other 2 volunteer units from Columbia University under George Brewer and from Cleveland under George Crile, Welles served admirably until January of 1919, and received a Royal Commendation of "warm appreciation" for his "invaluable service" from the King of England, personally signed George $R$. I., a memento that Welles' second- and third-generation descendants cherish to this day.

Shortly after returning from Europe, the distinguished veteran married his childhood sweetheart, Ruth Carver, in Sioux City, Iowa, the daughter of a Corn Belt Circuit Judge. The newlyweds were persuaded to move to Saranac Lake in upstate New York in 1921 by Dr Edwin Baldwin, a charter AATS member, inaugural AATS councilor, and long-time colleague of Dr Edward Livingston Trudeau, both renowned phthisiologists (tuberculosis specialists).

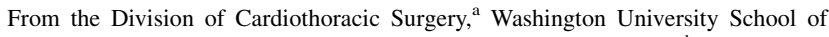
Medicine, St Louis, Mo; and Division of General Thoracic Surgery, ${ }^{\mathrm{b}}$ Mayo Clinic, Rochester, Minn.

Disclosures: Authors have nothing to disclose with regard to commercial support.

Received for publication Aug 22, 2013; accepted for publication Aug 27, 2013; available ahead of print Oct 17, 2013.

Address for reprints: Marc R. Moon, MD, Joseph C. Bancroft Professor of Surgery, Division of Cardiothoracic Surgery, Washington University School of Medicine, 660 S. Euclid Ave, Box 8234, Saint Louis, MO 63110 (E-mail: moonm@wustl. edu).

J Thorac Cardiovasc Surg 2014;147:553-5

$0022-5223 / \$ 36.00$

Copyright (C) 2014 by The American Association for Thoracic Surgery

http://dx.doi.org/10.1016/j.jtcvs.2013.08.057
}

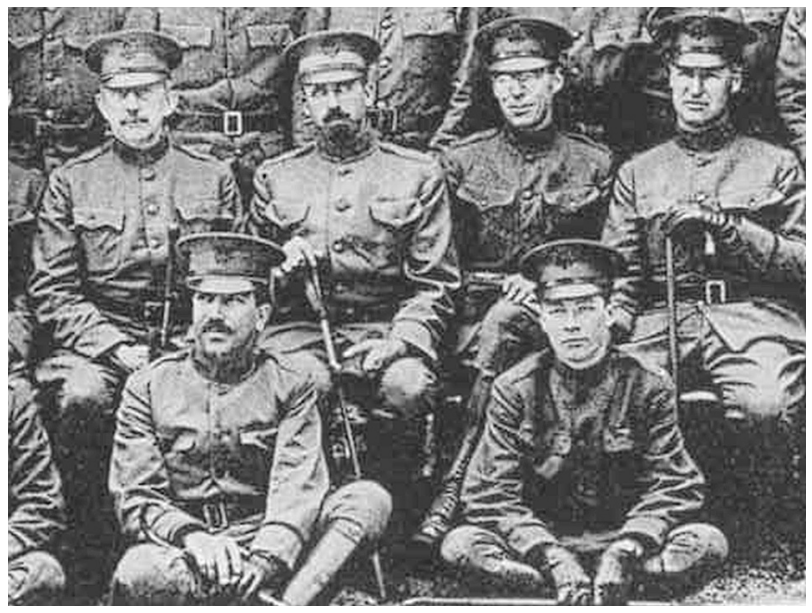

FIGURE 1. Captain Edward S. Welles (second from the right in the back row) near the Western Front, 1917.

Trudeau was a Columbia-trained physician who after being diagnosed with tuberculosis in 1871 was able to regain his health after spending 3 years at an open-air "Cure Cottage", in the Adirondack Mountains. Shortly thereafter, he permanently moved to Saranac Lake and founded the Adirondack Cottage Sanitarium and Saranac (Trudeau) Laboratory, which was the first laboratory in the United States dedicated to tuberculosis. Baldwin joined Trudeau in 1892, and after Trudeau's death in 1915, he directed the laboratory and sanitarium. Baldwin became aware of Welles' unyielding dedication to patient care and aggressive surgical experience with wounds of the chest and convinced him to take up practice in Saranac Lake as part of the tuberculosis team. Welles dedicated his career to the surgical treatment of pulmonary tuberculosis, the "great killer" of the first half of the 20th century.

The principal industry of Saranac Lake was tuberculosis for more than 2 generations, and in a community known for its outstanding physicians, Dr Welles was venerated by his peers and recognized as the "dean of chest surgeons." 4 He conducted extensive surgical experimentation on laboratory animals to test novel treatment options and became the thoracic surgical expert in collapse therapy, decortication, thoracoplasty, and resection for pulmonary disease. Welles presided over the 1955 AATS meeting in Atlantic City, and although the program lists "Remarks by the President, Edward S. Welles," his remarks were admittedly few. However, he did rise near the end of the meeting to comment on an issue that remains relevant today $^{5}$ : 


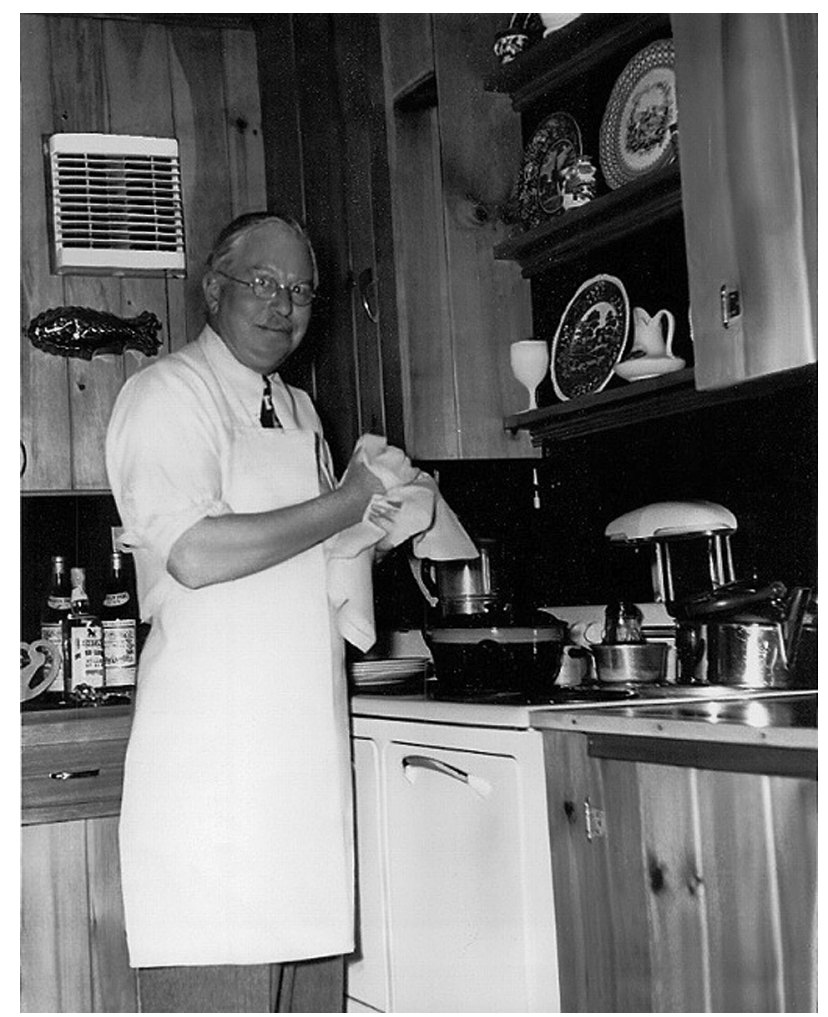

FIGURE 2. Dr Welles baking a cake for the Public Library Fair. "Attaboy!"

"I have been very quiet throughout this entire meeting, but at this time I want to compliment those who discussed this paper. All the discussions have been pertinent to the subject... I should like to call to the attention of the younger men particularly the fact that this is the type of discussion we ought to have."

Welles then went on to describe the problem he had identified with many previous discussants over the years:

"So many young men look over a program and find a subject that has some vague connection with what they want to say, so they take the opportunity to appear on the platform with a lot of statistics and present what is really a paper, although it would not be accepted as such."

Dr and Mrs Welles had 2 children and 6 grandchildren. $\mathrm{He}$ is remembered as witty, intelligent, commanding, and dynamic. He was a master trap/skeet shot, deer hunter, and woodsman. He also was an accomplished chef, receiving an emphatic "Attaboy!" in the local newspaper for volunteering to bake a cake for the Public Library Fair during his AATS presidential year (Figure 2). ${ }^{6}$ Dr Welles had many friends and was not shy to share his opinions. A columnist for the Adirondack Daily Enterprise once wrote

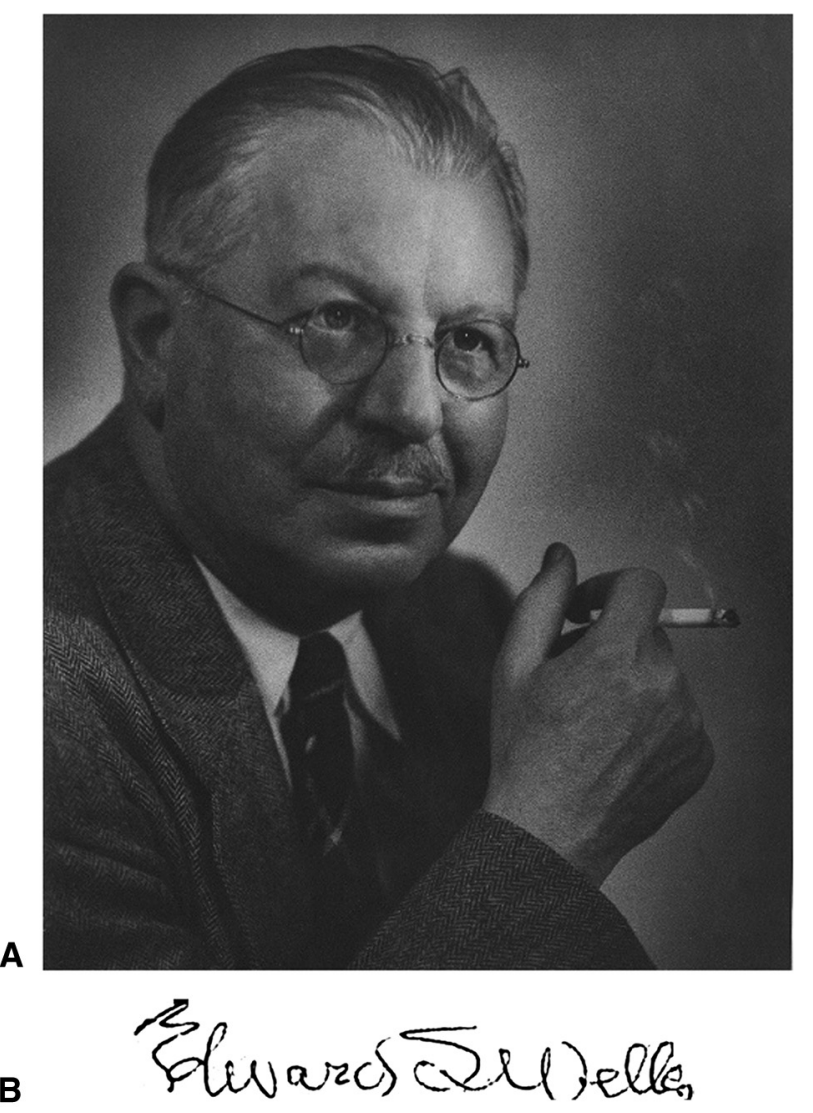

FIGURE 3. A, Dr Edward S. Welles. B, Signature of Edward S. Welles.

a column on the "incorruptible character" of Dr Welles, noting that his "curmudgeon-type personality with an outspoken way of talking was fundamental to the aura which surrounded him." " In the early 1950s, Dr Welles had one of the few televisions in town, but was often quoted for making salty remarks about the poor quality of television programming at the time. That being said, the townsfolk remember he put his television to good use one afternoon when, as a "passionate National Leaguer," he invited what seemed like half the town to his home to cheer on the Brooklyn Dodgers in their quest to oust the Yankees as champions in the 1953 World Series.

The Trudeau Sanatorium closed its doors during Dr Welles' presidency, which also coincided with the publication he welcomed after approximately 35 years of fighting tuberculosis. It was a report initiated by Welles and presented by his colleagues, noting that the combination of chemotherapy and lesser surgery could nearly eliminate the "Great Plague." ${ }^{8}$ Dr Welles' surgical practice ended shortly after his AATS presidency when he had a stroke, but he made a nice functional recovery and was able to enjoy his later years, eventually passing away February 24, 1967, after a relatively brief illness (Figure 3). 
The authors thank Dr Welles' grandchildren, Paula Welles Sheehan, Virginia (Gini) Heinsch, and Edward (Ted) Nutter for contributing their memories and old photographs for this retrospective.

\section{References}

1. Lamb AR. The Presbyterian Hospital and the Columbian-Presbyterian Medical Center 1868-1943: A History of a Great Medical Adventure. New York, NY: Columbia University Press; 1955.

2. Mullins RJ. A tradition of national service in times of crisis. Arch Surg. 2003;138: 1297-301
3. Dr Welles, 76 dead; noted chest surgeon. Obituary. Adirondack Daily Enterprise February 27, 1967:1.

4. Dr E. S. Welles elected VP of surgery association. Adirondack Daily Enterprise March 30, 1953:1.

5. Stranahan A, Alley RD, Kausel HW, Reeve TS. Operative thoracic ductography J Thorac Surg. 1956;31:183-98.

6. Loeb JI. Passing of an era. Adirondack Daily Enterprise. February 27, 1967:2

7. Vogt E. Our town. Adirondack Daily Enterprise. November 17, 1954:6.

8. Decker AM, Raleigh JW, Welles ES. The coordination of surgery and combined chemotherapy in the treatment of pulmonary tuberculosis. J Thorac Surg. 1955; 29:151-62. 